\title{
In vitro and In vivo Antiplasmodial of Stem Bark Extract of Garcinia husor
}

\author{
Healthy Kainama ${ }^{1,3}$, Sri Fatmawati ${ }^{1}$, Mardi Santoso' ${ }^{1}$, Pieter Kakisina ${ }^{2}$, Taslim Ersam ${ }^{1 *}$ \\ 'Laboratory of Natural products and Synthetic Chemistry, Department of Chemistry, Faculty of Sciences, Institut Teknologi Sepuluh \\ Nopember, Surabaya, Indonesia \\ ${ }^{2}$ Laboratory of Zoology, Department of Biology, Faculty of Mathematic and Natural Sciences, Universitas Pattimura, Ambon, \\ Indonesia \\ ${ }^{3}$ Department of Chemistry Education, Faculty of Teacher Training and Education, Universitas Pattimura, Ambon, Indonesia
}

\section{ARTICLE INFO}

Article history:

Received July 18, 2018

Received in revised form September 18, 2018

Accepted February 1, 2019

\section{KEYWORDS:}

Antiplasmodial,

Garcinia,

parasitemia,

P. berghei,

P. palcifarum

\begin{abstract}
Garcinia husor is one of the folk medicines in Maluku-Indonesia. This species has been used for the treatmet of Malaria disease. The phytochemical contents and antiplasmodial activity not reported yet. In this study we evaluated the quantitative phytochemicals, in vitro and in vivo antiplasmodial activity of stem bark ethyl acetate extract. In vitro assay was done using $P$. falciparum 3D7 strain sensitive of chloroquine. For in vivo analysis, four groups of $M$. musculus were infected by $P$. berghei and their parasitemia levels were for 7 days of treatment with ethyl acetate extract; hematological and biochemical parameter were analyzed at the end of experiment. The result showed ethyl acetate extract with the TPC (169.47 $\mathrm{mg} \mathrm{GAE} / 100 \mathrm{~g} \pm 0.61)$ and TPC $(167.37 \mathrm{mg} Q E / 100 \mathrm{~g} \pm 1.05)$ was active against $P$. falciparum 3D7 strain $\left(\mathrm{IC}_{50}\right.$ value of $\left.0.31 \pm 0.43 \mu \mathrm{g} / \mathrm{ml}\right)$. The animal treated with extract showed suppression of parasitemia to $87.57 \pm 1.41 \%$ compared with the $P$. berghei infected-mice (negative control), $\mathrm{ED}_{50}$ value of $22.30 \mathrm{mg} / \mathrm{kg} \mathrm{BW}$. The dose of extract in $200 \mathrm{mg} / \mathrm{kg}$ BW was reduce parasitemia of infected mice with $P$. berghei more potential. The ethyl acetate of the stem bark $G$. husor with has antiplasmodial properties and future investigation are necessary to elucidate its mechanism of action.
\end{abstract}

\section{Introduction}

Malaria is a major infectious disease with a high mortality in the developing country (Boampong et al. 2015). Until now, efforts have been made to treat this disease related to the development of alternative antimalarial, due to the emergence of drug-resistant strain. Many plants are used therapeutically in alternative and traditional medicine to treat infectious diseases. New and safe antimalarial drugs are urgently needed and natural products can represent a vast source of leading molecules (Oliveira et al. 2014).

Garcinia species are known to contain phenolic compounds such as xanthones, benzophenones, flavones, and depsidone (Nilar et al. 2005). Phenolic compounds showed that a wide range of biological

\footnotetext{
* Corresponding Author

E-mail Address: paktichem@gmail.com
}

and pharmacological properties, e.g. antioxidant, anti-inflammatory, antimicrobial, antiplasmodial, and cytotoxic activities (Minami et al. 1994; Vlientinck et al. 1998; Merza et al. 2006; Cos et al. 2008; Chin et al. 2008; Elfita et al. 2009). Benzophenones have been reported as anti-HIV, trypanocidal and cytotoxic agents (Gustafson et al. 1992; Vlietinck et al. 1998; Williams et al. 2003; Merza et al. 2006; Cos et al. 2008).

Garcinia husor (locally named "manggustan hutan" in Indonesia) is a medium sized tree ocurring in Maluku. In some Maluku communities, the stem bark of $G$. husor used in the treatment of malaria as endemic area but this has not been scientifically verified. This study was designed to evaluate the antimalarial potential of the ethyl acetate extract stem bark G. husor using Plasmodium falcifarum D37 strain in vitro and in vivo at $P$. berghei infected mice model. 


\section{Materials and Methods}

\subsection{Plant Material}

The stem bark of $G$. husor was collected from Allane Forest at Ambon island, Indonesia. This plant was identified and a voucher specimen (No. 52) was deposited at Biology Laboratory of Biology Departement, Pattimura University, Indonesia.

\subsection{Preparation of Extract}

The stem bark of G. husor were dried at room temperature and reduced to coarse powder using a disk mill SMJMA, FFC-15, Shandong Jimo. Dried stem bark powder (500 g) was mixed ethyl acetate and filtered. The solvent was evaporated under reduce pressure (Rotavapor R-210, Buchi, Switzerland) to obtain a solid mass extract of ethyl acetate (13.3\% $\mathrm{w} / \mathrm{w})$.

\subsection{Screening for Secondary Metabolites}

The ethyl acetate extract was screened for the presence of phytochemicals using standard procedures described elsewhere (Njoku and Obi 2009; Khan et al. 2011; Tiwari et al. 2011).

\subsection{Determination of TPC and TFC}

Total phenolic and flavonoid contents were determined by Folin-Ciocalteu's and aluminium chloride colometric methods, respectively (Singh et al. 2013) following quantification on the basis of standard curve of gallic acid (GAE) and quercetin $(\mathrm{QE})$ equivalent, respectively.

\subsection{Antimalarial Assays \\ 2.5.1. In Vitro Test}

The antimalarial activity of the extract was determined by the procedure described by Widyawaruyanti et al. 2007. In brief, extract dissolved in DMSO $\left(10^{-2} \mathrm{~mol} \mathrm{~L}-1\right)$ and kept at $-20^{\circ} \mathrm{C}$ until used. The malarial parasite $P$. falciparum 3D7 clone was propagated in a 24-well culture plate in the presence of a wide range of concentrations of each compound. The growth of the parasite was monitored by making a blood smear fixed with $\mathrm{MeOH}$ and stained with Geimsa stain.

$$
\begin{array}{ll}
\% \text { growth } & =\% \text { paristemia }-\mathrm{DO} \\
\% \text { inhibition } & =100 \%-((\mathrm{Xu} / \mathrm{Xk}) \times 100 \%)
\end{array}
$$

Where:

DO :\% growth at 0 o'clock

$\mathrm{Xu} \quad$ :\% growth at solution test

$\mathrm{Xk} \quad$ :\% growth at negative control
Based on percent inhibition data, an analysis was conducted between the concentration of the test and the percent inhibition using probit log analysis to determine the $\mathrm{IC}_{50}$ value or concentration of the extract which could inhibit parasite growth by $50 \%$.

\subsubsection{In Vivo Tests}

Animals and husbandry M. musculus weighing 20$24 \mathrm{~g}$ were obtained from Biology Laboratory Pattimura University, Indonesia. The animal were housed in stainless steel cages ( $34 \times 47 \times 18 \mathrm{~cm}$ ) with soft wood shaving as bedding, fed with normal commercial pellet diet given water ad libitum and maintaned under ambient laboratory conditions. All procedures and techniques used in these studies were in accordance with the National Institute of health Guidelines for the Care and Use of Laboratory Animals (NRC 1996). All ethical protocols used for the study were approved by the Departemental Ethics Committe.

\subsubsection{Animals}

Four-week-old M. Musculus from the Zoology Laboratory of Pattimura University were used in the experiments. Prior to the experimental produres, the animals were kept at $22 \pm 2^{\circ} \mathrm{C}$ on a $12 \mathrm{~h}$ dark-light, with balanced feed and water ad libitum for 15 days. All experiments were conducted in accordance with the internationally accepted principles for laboratory animal use and care adopted by the Animal Use Ethics committe of Airlangga University.

\subsubsection{Acute Toxicity Evaluation}

The acute toxicity assay was performed following the guidelines of The Organization for Economic Cooperation and Development (OCDE)-423/2001. When previous studies have assessed the acute toxicity of a known sample, the iniatial dose used can be the maximum dose without side effects. G. husor was tested in three groups of three animals each that were analyzed every 30 min during the first $4 \mathrm{~h}$, periodically for $24 \mathrm{~h}$ and daily until the $14^{\text {th }}$ day. Several parameters such as general activity, irritability, contortion, ataxia, tremors, convulsion, piloerection, hypothermia, breathing, cyanosis, hyperemia, and death were analyzed.

\subsubsection{Induction of the Experimental Malaria Model}

The malaria model was induced using the $P$. berghei ANKA ( $\mathrm{PbA})$ line. For the inoculation of the experimental groups, a blood drop from infected animals was collected from the terminal portion 
of the tail to analyze parasite density. The blood content of animals with a parasite density higher than $10 \%$ in the ascent phase was collected by cardiac puncture using an insulin syringe washed with the anticoagulant agent EDTA. To guarantee uniform parasitemia in the different experimental groups, animals were infected intraperitoneally with a standardized inoculum of approximately $10^{6}$ parasitized erythrocytes in $100 \mu$ PBS.

\subsubsection{Determination of Parasite Desity and Parasitemic Suppression}

Parasites were investigated in mouse tail blood smears fixed in absolute methanol for $2 \mathrm{~min}$ and stained with $10 \%$ Giemsa for $15 \mathrm{~min}$. Percent parasitemia was determined in each animal as the ratio between the quantity of parasitized erythrocytes and the total quantity of cells ( 500 cells per smear):

Parasitemia was determined on the $4^{\text {th }}$ days

$\%$ parasitemia $=\frac{\text { quantity of parasitized erythrocytes }}{500}$

post-inoculation of $\mathrm{BALB} / \mathrm{c}$ mice with $\mathrm{PbA}$ line. The model proposed by Girma et al. (2015) was used to determine the suppression potential of oleoresin against the parasitemia rate of $P$. berghei-infected mice.

\subsubsection{Experimental Design}

Mice were randomly divided into four groups of 3 animals each: Group 1 (G1), untreated P. bergheiinfected mice; Groups G2, G3, and G4, P. bergheiinfected mice treated orally with ethyl acetate $G$. husor stem bark extract, 10,100, and $200 \mathrm{mg} / \mathrm{kg} /$ day, respectivelly. Extract was suspended with 5\% CMC-Na as vehicle. All treatments began on the $4^{\text {th }}$ day after $P$. berghei inoculation, when parasite density was first determined to confirm infection. For the collection biological material at the end of treatment, animals were kept on their habitual diet without fasting due to the fragility of the malarial state.

\subsubsection{Statistical Analysis}

Data were analyzed statistically with Microsoft Excel 2010 and SPSS v22. Result were analyzed by ANOVA followed by LSD if significant difference. $p$ value $<0.05$ was considered statistically significant. All data were expressed as mean \pm SD (triplicate measurement).

\section{Results}

\subsection{Preliminari Phytochemical of Ethyl Acetate Extract}

The qualitative and quantative phytochemical of ethyl acetate extract was prepared from $G$. husor stem bark. The results of preliminary tests of different phytochemicals extract revealed the presence of alkaloid, terpenoids, flavonoid, tannins, and phenolics (Table 1).

The quantitative of phytochemical by determined of TPC (Total phenolic content) and TFC (Total flavonoid content) from extracts. The amount of total phenolic compounds present in extract was determined from linear regression equation of calibrate curve, $[\mathrm{y}=0.0045 \mathrm{x}+0.0481(\mathrm{R} 2=0.9581)]$ and expressed as Gallic acid equivalent in $\mathrm{mg} / \mathrm{ml}$ of extract. Table 1 depicts the result of assesment of total phenolic content in the tested extracts. It is found that, stem bark of G. husor $(\mathrm{p}<0.05)$ displayed high contents of total phenolics in aquoeus extracts showed $169.47 \mathrm{mg} \mathrm{GAE} / 100 \mathrm{~g} \pm 0.61 \mathrm{mg} \mathrm{GAE} / 100 \mathrm{~g}$.

The total flavonoid in extract was determined from linear regression equation of calibration curve obtained from the different concentration of quercetin $[\mathrm{y}=0.009 \mathrm{x}+0.0161(\mathrm{R} 2=0.983)]$ and the results was expressed as Gallic acid equivalent in $\mathrm{mg} /$ ml of extract(Table 1).However, extract demonstrated considerably high amount of flavonoids in stem bark G. husor with $167.37 \mathrm{mg} \mathrm{QE} / 100 \mathrm{~g} \pm 1.05$ (Table 1).

Table 1. Qualitative and quantitative phytochemical of ethyl acetate of $G$. husor stem bark extract

Secondary metabolites tested Ethyl acetate extract

Qualitative of phytochemical

Alkaloids

Terpenoids

Flavonoids

Saponin

Phenolics

Tannins

Quatitative of phytochemical

Total phenolic content $\quad 169.47 \mathrm{mg} \mathrm{GAE} / 100 \mathrm{~g} \pm 0.61^{\text {a }}$ Total flavonoid content $\quad 167.37 \mathrm{mg} Q E / 100 \mathrm{~g} \pm 1.05^{\mathrm{b}}$

+:present, -:undetected

a Results are expressed as gallic acid equivalents//100 g of extract

${ }^{b}$ Results are expressed as quercetin equivalents//100 $\mathrm{g}$ of extract

Value were performed in triplicated and represented as mean \pm SD. Level of significance: $(p<0.001)$ 


\subsection{In Vitro Antimalarial Activity}

The in vitro assay, antimalarial activity with the treatment of of G. husor stem bark ethyl acetate extract showed a decrease in parasite percentage of growth according to increased concentration, 0.01 $\mu \mathrm{g} / \mathrm{ml}$ (3.28\%); $0.1 \mu \mathrm{g} / \mathrm{ml}$ (2.54\%); $1 \mu \mathrm{g} / \mathrm{ml}(1.74 \%) ; 10$ $\mu \mathrm{g} / \mathrm{ml}(1.01 \%) ; 100 \mu \mathrm{g} / \mathrm{ml}(0.36 \%)$ (Figure 1a). Thus, the inhibition of parasite growth increased as the concentration increased, $0.01 \mu \mathrm{g} / \mathrm{ml}(22.89 \%) ; 0.1 \mu \mathrm{g} /$ $\mathrm{ml}$ (40.25\%); $1 \mu \mathrm{g} / \mathrm{ml}$ (59.04\%); $10 \mu \mathrm{g} / \mathrm{ml}$ (76.29\%); $100 \mu \mathrm{g} / \mathrm{ml}$ (91.55\%) (Figure 1b). Chloroquine as a positive control showed $100 \%$ inhibition at $100 \mu \mathrm{g} /$ $\mathrm{ml}$ concentration and the lowest inhibition of 59.09\%, this is equivalent to inhibition of the extract at $1 \mu \mathrm{g} /$ $\mathrm{ml}$ of concentration. Extract exhibiting $\mathrm{IC}_{50}$ value $\leq 10$ $\mu \mathrm{g} / \mathrm{ml}$ was cosidered to be active. Those exhibiting $\mathrm{IC}_{50}$ value in the range 10 to $\leq 10 \mu \mathrm{g} / \mathrm{ml}$ were considered moderately active. Extract exhibiting $\mathrm{IC}_{50}$ value $\geq 10 \mu \mathrm{g} / \mathrm{ml}$ was considered in active (Bagavan et al. 2011; Bunyong et al. 2014; Lima et al. 2015). Extract

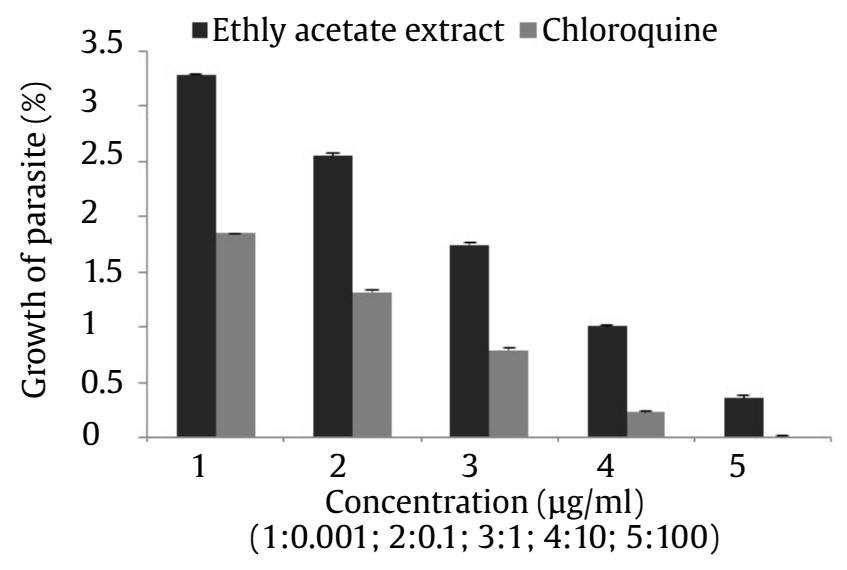

a

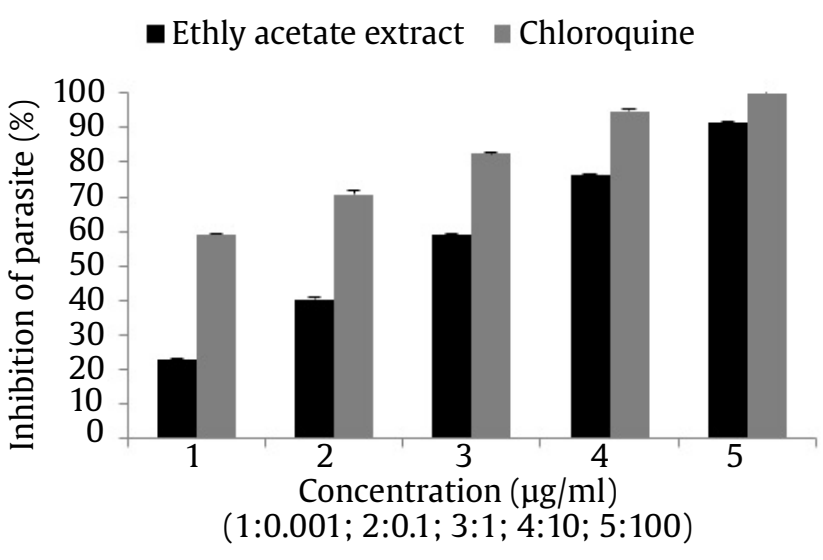

b

Figure 1. (a) Growth (\%) and (b) Inhibition (\%) of P. falcifarum incubated 48 hours with $G$. husor stem bark ethyl acetate extract. Value were performed in triplicated and represented as mean \pm SD. Level of significance: $(\mathrm{p}<0.001)$ ethyl acetate potent inhibitory activity, with an $\mathrm{IC}_{50}$ value of $0.31 \mu \mathrm{g} / \mathrm{ml}$ less than that antimalarial drug, chloroquine $\left(\mathrm{IC}_{50}, 0.006 \mu \mathrm{g} / \mathrm{ml}\right)$. The inhibitory activity of these extract supports the traditional use of the dried stem bark of G. husor as an antimalarial drug.

\subsection{In Vivo Antimalarial Activity \\ 3.3.1. Acute Toxicity Evaluation}

The administration of the maximum dose of ethyl acetate G. husor stem bark extract did not promote any changes such as loss of the hair or color, tremors, increased salivation, diarrheae, lethargy, increased or reduced sleep, pain or suffering, or weight loss.

Body weight is one of indicator that shows the state of malaria disease. Generally, in the P. bergheiinfected state, the body weight of the mice will decrease as the number of infected red blood cells increases. Thus, by observing the weight changes of the mice, it is hoped to know the relationship with the change of parasitemia number in mice. In Table $2, P$. berghei infection caused significant $(\mathrm{p}<0.05)$ decrease in the body weight-gain in the mice relative normal of all groups. All tested doses of the aquoeus extract significantly protected the mice from body weight loss. Thus it can be said that the extract is safe and effective as an antimalarial and does not significantly influence body weight loss of mice (Fentahun et al. 2017).

\subsubsection{Quantitative Analysis of the Evaluation of Parasitemia}

Quantitative analysis of number of parasites in blood samples collected on $4^{\text {th }}$ day post-inocultion showed level growth of parasite in the mean presentage of $\mathrm{G} 1$, infected only $(48.3 \pm 0.007 \%)$ higher than G2 (27.66 $\pm 0.06 \%)$, G3 $(21.66 \pm 0.01 \%), G 4$

Table 2. Effect of extract on the mean body weight in $P$. berghei infected mice

\begin{tabular}{lccc}
\hline Treatment & \multicolumn{2}{c}{ Body weight $(\mathrm{g})$} & Changes in body \\
\cline { 2 - 3 } & Initial & Final & weight $(\mathrm{g})$ \\
\hline $\begin{array}{c}\text { Infected only (G1) } \\
\text { Infected + extract } \\
\text { dose10 mg/kg }\end{array}$ & $20.17 \pm 0.05$ & $19.84 \pm 0.11$ & $-0.32 \pm 0.06$ \\
$\quad$ BW (G2) & & & \\
Infected + extract & $21.25 \pm 0.12$ & $21.20 \pm 0.11$ & $-0.05 \pm 0.02$ \\
$\quad \begin{array}{l}\text { dose 100 mg/ } \\
\text { kg BW (G3) }\end{array}$ & & & \\
Infected + ekstract & $21.93 \pm 0.29$ & $21.92 \pm 0.36$ & $-0.01 \pm 0.01$ \\
$\quad$ dose 200 mg/ & & & \\
kg BW(G4) & & & \\
\hline
\end{tabular}

Values are given as mean $\pm \operatorname{SD}(n=3)$

*Significantly different from normal $(\mathrm{p}<0.05)$ 
(6.0 $\pm 0.01 \%)$ (Figure 2). Effects of extract on P. berghei infected $M$. musculus. The results showed that an average percentage of inhibition against $P$. berghei of the infected only group (G1) and the infected treatment extract group (G2, G3, and G4) where the increased of dose treatment decrease percent growth of parasite. This indicates higher percentage of inhibition G4 (87.37\%) than G2 and G3. The G1 as negative control showed that higher growth of parasite $(48.30 \pm 8.17 \%$ ) and can not inhibit of parasite. So it can be said that ethyl acetate G. husor stem bark extract has good antimalarial activity because at a dose of $200 \mathrm{mg} / \mathrm{kg}$ BW showed percentage of inhibition $\geq 50 \%$ (Munoz et al. 2000).

Extract with persentage of inhibition $\geq 50 \%$ an in vivo assay at a dose of $100 \mathrm{mg} / \mathrm{kg}$ BW was classified as having excellent anti Plasmodium activity (Bantie et al. 2014; De Villiers et al. 2017). Based on this classification, the ethyl acetate G. husor stem bark extract have exelent antiplasmodial because at a dose of $100 \mathrm{mg} / \mathrm{kg}$ BW has been able to inhibit the growth parasite of $P$. berghei $\geq 50 \%$. Furthermore, probit analysis obtained $\mathrm{ED}_{50}$ value ethyl acetate $G$. husor stem bark extract of 22, $30 \mathrm{mg} / \mathrm{kg} \mathrm{BW}$.

The results of change level parasitemia by ANOVA test and futher analiysis LSD showed that a significant difference in the mean presentage of decrease of parasitemia, $\mathrm{p}<0.05 \mathrm{G} 1(0.01 \pm 0.07 \%), \mathrm{G} 2(0.10 \pm 0.06 \%)$, G3 $(0.24 \pm 0.01), G 4(0.34 \pm 0.01 \%)$. The result showed that parasitemia was reduced in all treated groups in relation to untreated $P$. berghei-infected mice (G1) (Figure 3). The infected untreat extract (G1) was significantly different with the doses of 10 (G2), 100 (G3), and $200 \mathrm{mg} / \mathrm{kg} \mathrm{BW} \mathrm{(G4),} \mathrm{the} \mathrm{dose} 10 \mathrm{mg} / \mathrm{kg}$ BW (G2) was not significantly different with the dose of $100 \mathrm{mg} / \mathrm{kg} \mathrm{BW}$ (G3), but the dose of $100 \mathrm{mg} / \mathrm{kg} \mathrm{BW}$ (G3) was significantly different with a dose of 200 $\mathrm{mg} / \mathrm{kg} \mathrm{BW}$ (G4).

Malaria infection also causes renal damage due to high parasitemia, when parasitized erythrocytes become hard, with reduced deformability and changes conformation. This increases blood viscosity, slowing and microcirculation and altering renal blood flow. Additionally, the cytoadherence of infected erythrocytes alters the local circulation, aggravating the renal injury. Our result showed that treatment with extract may contribute to an increase in the microcirculation, reducing erythrocyte cytoadhence, with a significant decrease of parasitemia.

The level of parasitemia is obtained from thin blood preparation by counting the number of infected cells $P$. berghei (ring-shaped trofozoid, advanced stage trofozoid, and schizon) in 1000 erythrocytes. Erythrocytes containing old trofozoites and schizons have obviously coarse points (Maurer's point) spread over two-thirds of the erythrocytes. The more trophozoites and schizons, the higher the level of parasitemia (Figure 4).
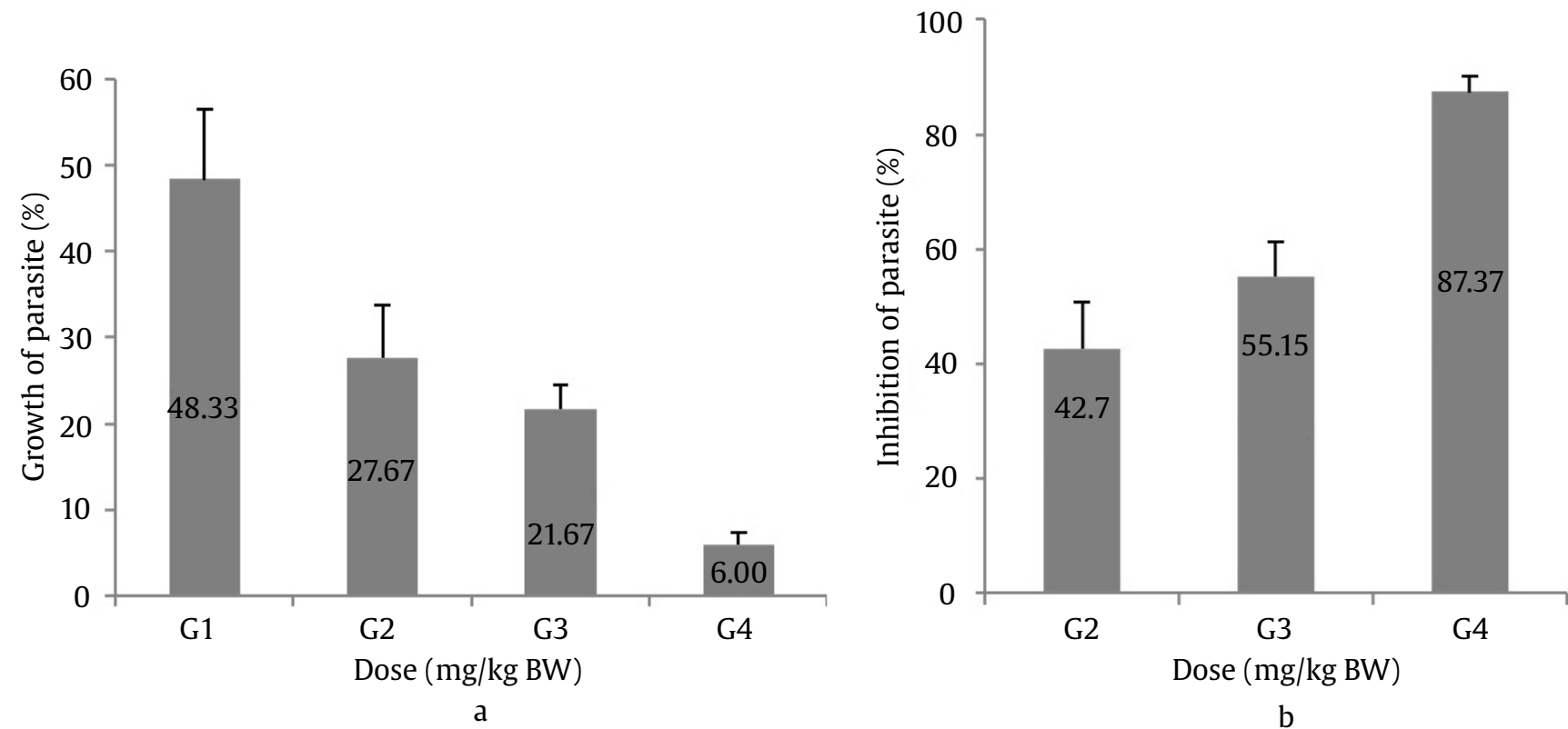

Figure 2. (a) Growth of parasite (\%) and (b) inhibition parasite (\%) in M. musculus. Each bar represents the mean \pm SD level parasitemia of animal belonging to G1 (of P. berghei infected-mice), G2 to G4 (aquoeus G. husor stem bark extract 10, 100, and 200 kg/BW), respectively). Significantly different $(\mathrm{p}<0.001)$ in level parasitemia of $\mathrm{G} 1$ compared to $\mathrm{G} 2-\mathrm{G} 4$ 


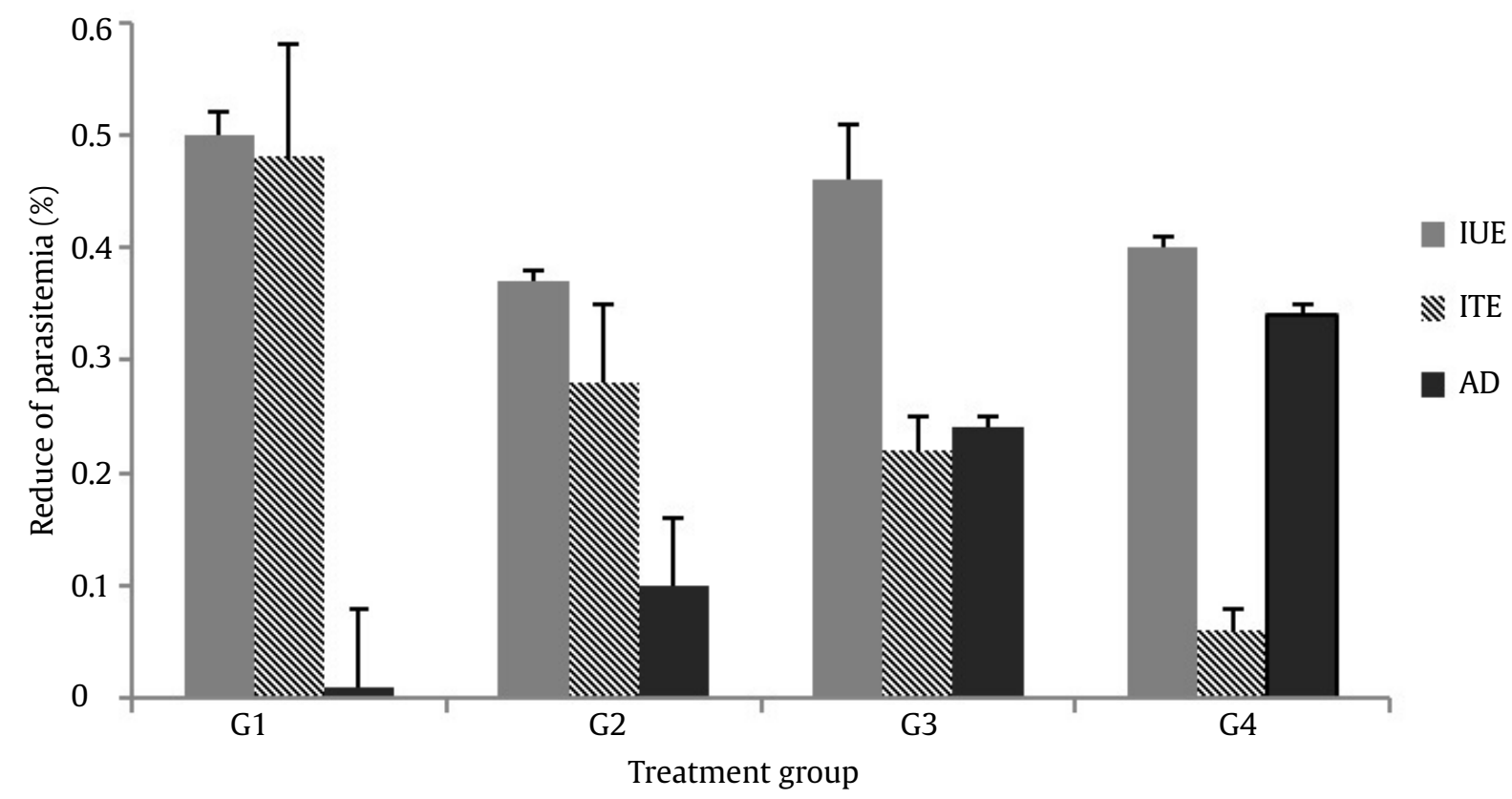

Figure 3. Reduce of parasitemia (\%). Each bar represents the mean \pm SD reduce parasitemia of animal belonging to G1 (of P. berghei infected-mice), G2 to G4 (ethyl acetate G. husor extract 10, 100, and $200 \mathrm{~kg} / \mathrm{BW}$ ), respectively). IUE: infected untreated of extract; ITE: Infected treatment extract, AD: average of difference. Significantly different $(\mathrm{p}<0.05)$ inreduce of parasitemia of G1 compared to G2-G4

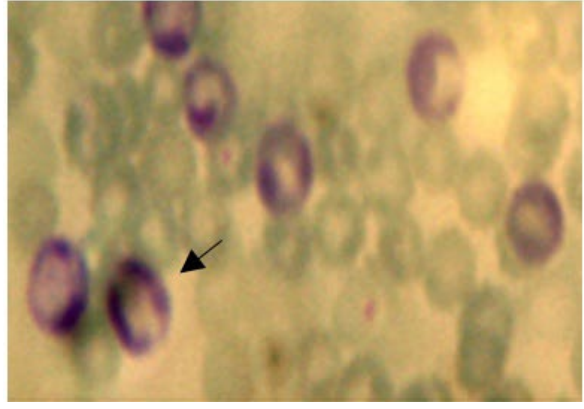

a

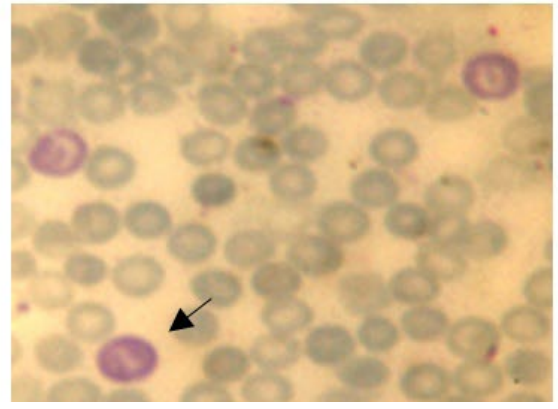

b

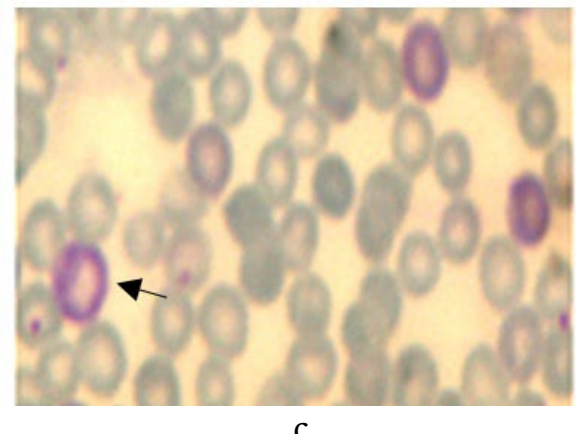

C

Figure 4. Microscopic evidence of erythrocytic is infected with P. berghei after treatment antimalarial activity of G. husor extract. Infected erythrocytes (trofozoite ring form) are indicated by arrows. (a) dose $10 \mathrm{mg} / \mathrm{kg} \mathrm{BW}$, (b) dose 100 $\mathrm{mg} / \mathrm{BW}$, (c) Dose $200 \mathrm{mg} / \mathrm{BW}$

\section{Discussion}

During the prospection of new subtances with antimalarial potential an important feature is required: the subtances must present reduced $\mathrm{IC}_{50}$ value assays, minimizing the lack of drug specifity and side effect (de Souza et al. 2017). Extract have $\mathrm{IC}_{50}$ value $\leq$ to $P$. falcifarum can be continued to isolation of active compounds in medicinal plant (Oliveira et al. 2014). Ethyl acetate $G$. husor stem bark extract showed reduced IC $_{50}$ value $(0.31$ $\mu \mathrm{g} / \mathrm{ml}$ ) against $P$. falcifarum 3D7 strain. Moreover, it is expected that a potent antimalarial agent (Katusno et al. 2015) and be continue in vivo antimalaria assay.
The present results shown a low toxicity of ethyl acetate extract even at doses higher than used in the study. The absence of clinical features of toxicity or weight variation is important, mainly because in the malaria state the animal can present symptoms belonging to both states such as pelage change, lethargy and weight loss which could interfere which the results.

The observation that no death caused by an oral highest dose of $200 \mathrm{mg} / \mathrm{kg}$ body weight of ethyl acetate extract of the G. husor stem bark could imply the safety of the plant to be used in the treatment of Malaria as also suggested in Akele et al. 2013 and Murithi et al. 2014. The acute toxicity result of the present study suggested that 
the oral extract at the highest dose $(200 \mathrm{mg} / \mathrm{kg} \mathrm{BW})$ and included in the category of practically non-toxic (OECD 2008). The experimental determination of acute toxicity at the extract dose of up to $2000 \mathrm{mg} / \mathrm{kg}$ body weight of mice may justify the use of this plant for malaria treatment.

In vivo antiplasmodial activity can be classified as moderate, good and very good if an extract displayed a respective percent parasite suppression equal to or greater $50 \%$ at doses of 500,250 , and $100 \mathrm{mg} / \mathrm{kg}$ body weight per day (Munoz et al. 2000; Deharo et al. 2001). Based on this classification, the extract of $G$. husor are considered to exhibit good antiplasmodial activity, with dose dependent inhibition against $P$. berghei infection in mice.

Malaria is an inflammatory cytokine-driven disease that often results in mortality due to sequestered parasitized red cells preventing sufficient oxygen access to where it is needed together with mitochondria inability to generate enough adenosine triphosphate to maintain normal cellular function (Clarck et al. 2010). $P$. berghei parasite is used in predicting treatment outcomes of any suspected antimalarial agent due to its high sensitivity to chloroquine, making it the appropriate parasite for this study (Boampong et al. 2015). In this study, three doses of the ethyl acetate stem bark extracts of G. husor exerted curative antimalarial activities against the blood stage of $P$. berghei. Ethyl acetate extract give high effect for reduce level of parasitemia in dose $100 \mathrm{mg} / \mathrm{kgBW}$ $24 \pm 0.01 \%$ and $87.37 \pm 1.41 \%$ inhibition of parasite of $P$. berghey-infected mice. This result showed that effect ethyl acetate extract lower than treated orally dose $100 \mathrm{mg} / \mathrm{kg}$ BW with artemisinin were $54 \pm 0.14 \%$; $95 \%$, respectivelly (de Souza et al. 2017). This implies that the active principles for the observed antimalarial effects are present in ethyl acetate extract. It is proposed that the presence of alkaloids, triterpenoids, flavonoids, phenolics, and tannins could be responsible for the observed curative antiplasmodial activities of the extract but further experiments are needed to confirm this hypothesis. Some alkaloids that act against malaria parasites inhibit protein synthesis by intercalating with DNA of the parasite (Okokon et al. 2008; Christian et al. 2012). In addition, flavonoids and tannins have been suggested to act as primary antioxidants or free radical scavengers that can counteract the oxidative damage induced by the malaria parasite (Gautam et al. 2011; Kayani et al. 2016). Numerous studies have implicated oxidative stress in several pathological conditions such as stroke, diabetes, Parkinson's disease and so on. Apart from their detrimental effects, free radicals are also involved in cellular signaling and as carriers for iron requirement needed by parasites for survival in a host. Iron is a crucial nutrient for survival and replication of microorganisms such as Plasmodium parasites. Thus, the ability of an antioxidant to chelate/sequester iron needed by the Plasmodium parasite will adversely affect the survival of the parasite in a host. Flavonoids in particular have the ability to chelate iron and they have been suggested that such compounds with the ability to sequester iron should be employed in treatment of infections (Chandrashekaran et al. 2010). Ethyl acetate extract have high total flavonoid content, which possibly contributed to the antiplasmodial effect observed in the mice. Some terpenoids attack the broadest age range of parasites, from the tiniest rings that have recently invaded erythrocytes to more mature stages of parasites such as developing trophozoites and schizonts. Their relatively broad stage-specificity of action has been reported to extend to the ability to impede development of gametocytesm (Yoo et al. 2008; Coma-cros et al. 2018). The data provide evidence that stem bark extracts of G. husor antiplasmodial activity which may partly be mediated by its phytochemical compounds.

In the qualitative and quantitative analysis of this plant studied, some of these secondary metabolites were present and saponin was absent. It has been reported that several plant constituents, vis; flavonoid, tannins, xanthone, phenolic, and triterpenoid posses protein-binding and enzim-inhibiting properties (Selvanayagam and Ghanavendhan 1995; Fale et al. 2012; Oluwatosin et al. 2014). The likely mechanism of action of this extract contain flavanoid may be inhibition of key pathognic enzymes of the parasite since extract is known to interference with enzymes sistem (Okunji et al. 2007; Penduka et al. 2011). Alkaloids are important phytochemicals, that are said to be pharmacologically active. Quinine, an alkaloid, is popular for is antimalaril activity against the malaria parasite (Bankole et al. 2016). Triterpen, 3b-hydroxy-23-oxo-9,16-lanostadien26-oic acid or garcihombronane D from G. celebica showed a selective activity against $P$. falcifarum (Elfita et al. 2009).

Pearson's correlation coefficient ( $r$ ) showed high and positive correlation between phenolic content in extract with antimalarial activity (Table 3 ). In the 
Table 3. Pearson's correlation coefficient ( $r$ ) of TPC, TFC ethyl acetate G. husor stem bark extract and antimalarial activity

\begin{tabular}{lllll}
\hline & TPC & TFC & APf & APb \\
\hline TPC & $1^{*}$ & & & \\
TFC & $0.888^{*}$ & $1^{*}$ & & \\
APf & $0.904^{*}$ & $0.999^{*}$ & $1^{*}$ & \\
APb & $0.747^{*}$ & $0.968^{*}$ & $0.959^{*}$ & $1^{*}$ \\
\hline
\end{tabular}

present study, TPC and TFC to be analytical markers since they were the major components of the test sample. Similarly, phenolic were have confirmed its antimalarial activity. On the other hand, due to the complexity of the sample, it is difficult to state that molecule is responsible for the antimalarial potential of extract, with a synergistic effect probably playing an important role in the activity.

The previous studies reported that phenolic components from Garcinia genus have antimalarial potential i.e. $\alpha$ and $\beta$-mangostin (G. mangostana) 1,5-dihidroksi-3,6-dimetoksi-2,7-diprenilsanton isosantoximol (G. griffithii), kolaviron (G. cola) (Mahabusarakham et al. 2006; Oluwatusin et al. 2014).

Malaria infection also causes renal damage due to high parasitemia, when parasitized erythrocytes become hard, with reduced deformability and changes conformation. This increases blood viscosity, slowing and microcirculation and altering renal blood flow. Additionally, the cytoadherence of infected erythrocytes alters the local circulation, aggravating the renal injury. Our result showed that treatment with extract may contribute to an increase in the microcirculation, reducing erythrocyte cytoadhence, with a significant decrease of parasitemia.

The present study revealed that ethyl acetate stem bark G. husor extract effective herb with significant antiplasmodium in vitro test antiplasmodium against P. falcifarum 3D7 strain and in vivo test in M. musculus infected $P$. berghei (ANKA) strain. The biological activities observed in the study could be attributed to the higher phenolic and flavonoid contents of the extract. The result obtained in this study demosntrated that the ethyl acetate of G. husor stem bark extract potent antimalaria activity. However, this appears to the first report of antimalarial properties of stem bark G. husor extract in vitro and in vivo research. The result of this study suport the traditional claim of the plant in the use for malaria treatment, and effort are currently underway to identify the bioactive components of the plant and toxicological effects in animals.
The overall, result showed that ethyl acetate of $G$. husor stem bark in vitro and in vivo has good activities as antipalsmodial. Furthermore that can be used as antimalarial drugs alternative or as a combination with antimalarials other.

\section{Acknowledgements}

We wish to acknowledgement to the Ministry of Research, Technology and Higher Education of the Republic Indonesia for the financial support for research in scheme Grant Competitive and Grant Post Graduate in the year of 2018.

\section{References}

Akele B. 2013. In vivo antimalarial activity of areal parts extracts of Gardinea lutea and Sida rhombifolia. IJRPP 2:234-41.

Bagavan A et al. 2011. In vitro antimalarial activity of medicinal plant extracts against Plasmodium falcifarum. Parasitol Res 108:15-22.

Bankole AE et al. 2016. Phytochemical screening and in vivo antimalarial activity of extracts from three medicinal plants used in malaria treatment in Nigeria. Parasitol Res 115:299-305.

Bantie L et al. 2014. In vivo antimalarial activity of the crude leaf extract and solvent fractions of Croton macrostachyus Hocsht. (Euphorbiaceae) against Plasmodium berghei in mice. BMC Complement Alter Med 14:79.

Boampong JN et al. 2015. In vivo antiplasmodial and in vitro antioxidant properties of stem bark extracts of Haematostaphis barteri. Asian Pac J Trop Biomed 5:446-450.

Bunyong R et al. 2014. Antimalarial activity and toxicity of Garcinia mangostana Linn. Asian Pasific J of Trop Med 7:693- 698.

Chandrashekaran IR et al. 2010. Inhibition by flavonoids of amyloid-likef fibril formation by Plasmodium falciparum merozoite surface protein 2. Biochemistry 49:5899-5908.

Chin $\mathrm{Y}$ et al. 2008. Xanthones with quinone-reductase inducing activity from the fruits of Garcinia mangostana (Mangosteen). Phytochemistry 69:754758.

Christian AG et al. 2012. Antimalarial potency of the leaf extract of Aspilia africana (Pers.) C.D. Adams. Asian Pac J Trop Med 5:126-129.

Clark IA et al. 2010. The roles of TNF in brain dysfunction and disease. Pharmacol Ther 128:519-548.

Coma-Cros EM et al. 2018. Antimalarial activity of orally administered curcumin incoporated in eudragit ${ }^{(\mathrm{R})_{-}}$ containing liposomes. Inter J of Molecular Sci 19:13611372.

Cos $\mathrm{P}$ et al. 2008. Plant derived leading compounds for chemotherapy of human immunodeficiency virus (HIV) Infection-an update (1998-2007). Planta Med 74:1323-1337. 
De Villiers M et al. 2017. Antiplasmodial mode of action of pantothenamides: panthothenate kinase serves as a metabolic activator, not a target. ACS Infectiois Diseases 3:527-541.

Deharo E et al. 2001. A search for national bioactive compiunds in Bolivia through a multidisciplinary approach: part $\mathrm{v}$. evaluation of the antimalarial activity of plants used by the Tecana Indians. $J$ Ethnopharmacol 77:91-98.

de Souza GAG et al. 2017. In vitro and in vivo antimalarial potential of oleoresin obtained from Copaifera reticulata Ducke (Fabaceae) in the Brazilian Amazon rainforest. Phytomedicine 24:111-118.

Elfita E et al. 2009. Antiplasmodial and other constituents from four Indonesian Garcinia spp. Phytochemistry 70:907-912.

Fale PLA et al. 2012. Acetyl-cholinestrase inhibition, antioxidant activity and toxicity of Peumus boldus water extracts on HeLa and CaCo-2 cell lines. Food chem Toxicol 50:2656-5662.

Fentahun $\mathrm{S}$ et al. 2017. In vivo antimalarial activity of crude extracts and solvent fractions of strychnos mitis in Plasmodium berghei infected mice. BMC Complementary and Alternative Medicine 17:13-25.

Gautam R et al. 2011. Anti-inflammatory effect of Ajuga bracteosa wall ex benth. Mediated through cyclooxygenase (COX) inhibition. J Ethnopharmacol 133:928-930.

Girma S et al. 2015. Effect of crude leaf extract of Osyris quadripartita on Plasmodium berghei in Swiss albino mice. BMC Complem Altern M 15:1-9.

Gustafson KR et al. 1992. The guttiferones, HIV inhibitory agents from Symphonia globulifera, Garcinia livingstonei, Garcinia ovalifolia, and Clusia rosea. Tetrahedron 48:10093-10102.

Katsuno K et al. 2015. Hit and lead criteria in drug discovery for infectious deseases of the developing world. Nature Rev Drug Discov 14:751-758.

Kayani WK et al. 2016. Evaluation of Ajuga bracteosa for antioxidant, anti-inflammatory, analgesic, antidepressant, and anticoagulant activities. BMC Compl and Alter Med 16:375-388.

Khan AM et al. 2011. Phytochemical analysis of selected medicinal plants of Margalla Hills and surroundings. J of Med Plants Res 5:6017-6023.

Lima RBS et al. 2015. In vitro and in vivo anti-malarial activity of plants from the Brazilian Amazon. Malaria J 14:508-521.

Mahabusarakam W et al. 2006. Prenylated xanthonesas potential antiplasmodial subtances. Planta Med 72:912-916.

Merza J et al. 2006. New cytotoxic guttiferone analogues from Garcinia virgata from New Caledonia. Planta Med 72:87-89.

Minami H et al. 1994. Antioxidant xanthones from Garcinia subelliptica. Phytochemistry 36:501-506.

Munoz V et al. 2000. The search for natural bioactive compounds through a multidisciplinary approach in Bolivia. Part II antimalarial activity of some plants used by Mosetene Indians. J of Ethnopharmacol 69:139-55.
Murithy CK et al. 2014. Antimalarial activity and in vivo toxicity of selected medicinal plants naturalised in Kenya. Int J Edu Res 2:395-406.

Nilar et al. 2005. Xanthones and benzophenones from Garcinia griffithii and Garcinia mangostana. Phytochemistry 66:1718-23.

Njoku OV, Obi C. 2009. Phytochemical constituents of some selected medicinal plants. African J of Pure and Applied Chem 3:228-233.

[NRC] National Research Council. 1996. Guide for the Care and Use of Laboratory Animals. $7^{\text {th }}$ ed. Washington, DC: National Akademy Press.

[OECD] Organisation for Economic Cooperation and Development. 2008. Test No. 425: acute oral toxicity: Up and down procedure. Paris: OECD Publishing. http://dx.doi.org/10.1787/9789264071049-en

Okokon JE et al. 2008. In vivo antimalarial activity of ethanolic leaf extract of Stachytarpheta cayennensis. Indian J Pharmacol 40:111-113.

Okunji C et al. 2007. Preparative isolation and identification of tyrosinase inhibitors from the seeds of Garcinia kola by high-speed counter-curent chromatography. J of Chromatography A 1151:45-50.

Oliveira et al. 2014. Ethnopharmacological studies of Lippia origanoides. Rev Bras Farmacogn 24:206-214.

Oluwatosin A et al. 2014. Antimalarial potential of kolaviron, a biflavonoid from Garcinia kola seeds, against Plasmodium berghei infection in Swiss albino mice. Asian Pacific Journal of Trop Med 7:97-104.

Penduka D et al. 2011. In-vitro antagonistic charateristic of crude aqueous and methanolic extracts of Garcinia kola (Heckel) seeds against some Vibrio bacteria. Molecules 16:2754-2765.

Selvanayagam Z, Ghanavendhan S. 1995. Antinake venom botanical from ethnomedicine. J Herbs spices Med Plants 2:45-100.

Singh RSG et al. 2013. Phenolic composition, antioxidant and antimicrobial activities of free and bound phenolic extracts of Moringa oleifera seed flour. $J$ of func foods 5:1883-1891.

Tiwari V et al. 2011. Pharmacognostical, phytochemical, antimicrobial evaluation of Bauhinia tomentosa Stem. J of Pharm Res 4:1173-1175.

Vlietinck A et al. 1998. Plant derived leading compounds for chemotherapy of human immunodefficiency virus (HIV) infection. Planta Med 64:97-109.

Widyawaruyanti A et al. 2007. New prenylated flavones from Artocarpus champeden and their antimalarial activity in vitro. J Nat Med 61:410-413.

Williams RB et al. 2003. A novel cytotoxic guttiferone analogue from Garcinia macrophylla from the Suriname rainforest. Planta Med 69:861-864.

Yoo $\mathrm{H}$ et al. 2008. Antiangiogenic, antinociceptive anti intiinflammatory activities of Lonicera japonica extract. J of Pharmacy and Pharmacology 60:779-786. 